Ethnography in Today's World 


\section{HANEY FOUNDATION SERIES}

A volume in the Haney Foundation Series, established in 1961 with the generous support of Dr. John Louis Haney 


\section{Ethnography in Today's World}

Color Full Before Color Blind

\section{Roger Sanjek}

\section{$\overline{\text { PENN }}$}

UNIVERSITY OF PENNSYLVANIA PRESS

PHILADELPHIA 
Copyright (C) 2014 University of Pennsylvania Press

All rights reserved. Except for brief quotations used for purposes of review or scholarly citation, none of this book may be reproduced in any form by any means without written permission from the publisher.

Published by

University of Pennsylvania Press

Philadelphia, Pennsylvania 19104-4112

www.upenn.edu/pennpress

Printed in the United States of America on acid-free paper

109876554321

Library of Congress Cataloging-in-Publication Data

Sanjek, Roger, 1944-

Ethnography in today's world : color full before color blind / Roger Sanjek.-1st ed. p. cm. - (Haney foundation series)

Includes bibliographical references and index.

ISBN 978-0-8122-4545-5 (hardcover : alk. paper)

1. Ethnology—United States—Methodology. 2. Ethnology—Methodology.

3. Anthropology—United States—Methodology. 4. Anthropology-Methodology.

I. Title.

GN345.S255 2014

$305.800973-\mathrm{dc} 23$ 
For my teachers: Anne Schwerner, Robert Stigler,

Marvin Harris, Lambros Comitas, Jaap van Velsen, George C. Bond, Allen Johnson 
This page intentionally left blank 